\title{
PENGARUH MODEL PEMBERDAYAAN BERPIKIR MELALUI PERTANYAAN TERHADAP KEMAMPUAN BERPIKIR KREATIF SISWA DI SMP NEGERI 10 KUPANG
}

\section{(THE EFFECT OF THINKING EMPOWERMENT MODELS THROUGH QUESTIONS ON THE CREATIVE THINKING ABILITY OF STUDENTS IN SMP NEGERI 10 KUPANG)}

\author{
Novi R. Lingu ${ }^{1)}$, Fransina Th. Nomleni ${ }^{1)}$, Theodora S. N. Manu ${ }^{1)}$ \\ 1'Program Studi Pendidikan Biologi, Fakultas Keguruan dan IImu Pendidikan, Universitas Kristen \\ Artha Wacana Kupang-NTT \\ Corresponding author : novirosina@gmail.com
}

\begin{abstract}
ABSTRAK
Permasalahan utama pada penelitian ini adalah kurangnya kemampuan berpikir kreatif siswa kelas VIII SMP Negeri 10 Kupang. Tujuan penelitian untuk mengetahui pengaruh model pemberdayaan berpikir melalui pertanyaan terhadap kemampuan berpikir kreatif siswa. Metode yang digunakan adalah metode eksperimen dengan desain post test-only control design. Populasi seluruh siswa kelas VIII berjumlah 327 siswa dan sampel kelas $\mathrm{VIIIH}$ dan kelas $\mathrm{VIIIJ}$ berjumlah 64 siswa. Teknik pengambilan sampel yang digunakan adalah purposive sampling. Pengumpulan data dilakukan dengan tes berpikir kreatif. Teknik analisis data menggunakan Uji t, dengan bantuan software SPSS versi 19. Berdasarkan hasil uji hipotesis diperoleh nilai Sig. (2-tailed) $<0,05$ artinya terdapat pengaruh penggunaan model pemberdayaan berpikir melalui pertanyaan terhadap kemampuan berpikir kreatif siswa Hasil penelitian juga menunjukkan persentase kemampuan berpikir kreatif pada kelas eksperimen lebih tinggi pada indicator kelancaran $=$ $89,45 \%$, keaslian $=89,06 \%$, merinci $=82,03 \%$, dan keluwesan $=77,34 \%$ dibandingkan dengan kemampuan berpikir kreatif pada kelas Kontrol..
\end{abstract}

Kata Kunci : model PBMP, berpikir kreatif, materi biologi

\begin{abstract}
The main problem of this research is the lack of creative thinking ability of VIII grade students of SMP Negeri 10 Kupang. The research objective is to determine the effect of thinking empowerment models through questions on students' creative thinking abilities. The method used is an experimental method with posstestonly control design. The population of all students in class VIII was 327 students and the sample in class VIIIH and class VIIIJ was 64 students. The sampling technique used is purposive sampling. Data collection is done by creative thinking tests. Data analysis techniques used the t test, used SPSS software version 19. Based on the results of the hypothesis test, the Sig. (2-tailed) $<0.05$ means that there is an effect of using the empowerment model of thinking through questions on students' creative thinking abilities. The results also show that the percentage of creative thinking skills in the experimental class is higher on indicators of fluency $=89.45 \%$, authenticity $=89.06 \%$, detailing $=82.03 \%$, and flexibility $=77.34 \%$ compared to the creative thinking ability in the Control class.
\end{abstract}

Keywords : Model PBMP, creative thinking, biology 


\section{PENDAHULUAN}

Pembelajaran merupakan bantuan yang diberikan pendidik agar dapat terjadi proses pemerolehan ilmu dan pengetahuan, penguasaan kemahiran dan tabiat, serta pembentukan sikap dan kepercayaan pada peserta didik. Menurut Mulyana (2008) pembelajaran merupakan setiap usaha yang sistematis dan disengaja untuk menciptakan kondisi-kondisi agar terjadi kegiatan belajar membelajarkan. Oleh karena itu dalam pembelajaran guru perlu menciptakan suasana yang kondusif dan strategi belajar yang menarik minat siswa.

Proses pembelajaran adalah proses yang di dalamnya terdapat kegiatan interaksi antara guru-siswa dan kombinasi timbal balik yang berlangsung dalam situasi edukatif untuk mencapai tujuan belajar (Rustaman, 2001). Dalam proses pembelajaran, guru dan siswa merupakan dua komponen yang tidak bisa dipisahkan. Antara kedua komponen tersebut harus terjalin interaksi yang saling menunjang agar hasil belajar siswa dapat tercapai secara optimal. Komponen lain yang juga mendukung proses pembelajaran salah satunya adalah model pembelajaran.

Model pembelajaran adalah seluruh rangkaian penyajian materi ajar yang meliputi segala aspek sebelum, sedang, dan sesudah pembelajaran yang dilakukan guru serta segala fasilitas yang terkait yang digunakan secara langsung atau tidak langsung dalam proses belajar (Istarani, 2011). Model pembelajaran adalah unsur penting dalam kegiatan belajar mengajar untuk mencapai tujuan pembelajaran. Model pembelajaran digunakan guru sebagai pedoman dalam merencanakan pembelajaran di kelas serta mewujudkan suasana belajar yang melibatkan siswa terlibat aktif dalam proses pembelajaran. Salah satu model pembelajaran yang bisa digunakan adalah model pemberdayaan berpikir melalui pertanyaan (PBMP).

Model PBMP merupakan model pembelajaran yang dalam proses pembelajarannya mengupayakan pemberdayaan daya pikir siswa melalui pertanyaan. Pertanyaan-pertanyaan tersebut disusun sedemikian rupa, sehingga membentuk suatu pola, yang secara berurutan meliputi sediakan, lakukan, renungkan, pikirkan, dan evaluasi, serta kemudian diakhiri dengan arahan. Kelebihan PBMP adalah siswa mampu mengingat materi dan mampu menjawab melalui media, teknologi, dan pembelajaran berpikir akan kehidupan sesungguhnya, sehingga timbul pemikiran dan pertanyaan lanjutan dari siswa sendiri ( Corebima, 2014).

Berpikir kreatif merupakan suatu kegiatan berpikir yang dimulai karena adanya kesadaran terhadap sesuatu masalah yang menuntut seseorang untuk secepatnya menyelesaikan masalah tersebut. Munandar (2009) mengemukakan bahwa berpikir kreatif adalah kemampuan untuk membuat kombinasi baru berdasarkan data, informasi, maupun unsur-unsur yang sudah ada atau yang sudah dikenal sebelumnya. Unsur-unsur tersebut berdasarkan semua pengalaman dan pengetahuan yang telah diperoleh seseorang selama hidupnya baik itu di lingkungan sekolah, keluarga maupun dari lingkungan masyarakat. Model PBMP memiliki hubungan dengan kemampuan berpikir kreatif hal ini karena model PBMP dapat mengatasi masalah-masalah berpikir terutama berhubungan dengan berpikir kreatif.

Berdasarkan hasil observasi di SMP N 10 Kupang di kelas VIII pada saat proses pembelajaran menunjukkan kurangnya kemampuan berpikir kreatif, baik itu indikator kemampuan berpikir lancar, berpikir orisinil, merinci maupun kemampuan berpikir luwes. Masalah yang berkaitan dengan indikator berpikir lancar yang dialami siswa dilihat dari kesulitan siswa dalam menghasilkan gagasan-gagasan yang relevan. Masalah indikator berpikir luwes yaitu dilihat dari siswa kurang menghasilkan gagasan-gagasan yang seragam. Masalah yang berkaitan dengan indikator berpikir orisinil dilihat dari siswa tidak dapat memberikan jawaban yang bervariasi dan memberikan pendapat atau pemikiran yang berbeda dari temannya. Masalah dari indikator berpikir merinci yaitu siswa belum mampu mengembangkan suatu gagasan dan memperluas suatu gagasan. Selain itu, kurangnya kemampuan berpikir kreatif terjadi karena kurangnya aktifitas belajar siswa. Hal ini terlihat dari siswa pasif dalam menjawab dan mengajukan pertanyaan serta ketidakmauan siswa untuk bertukar informasi tentang materi yang dipelajari.

Kemampuan siswa untuk memahami materi pembelajaran juga masih rendah karena kurangnya penggunaan model pembelajaran yang bervariasi. Pada saat guru menjelaskan materi pembelajaran beberapa siswa sibuk dengan kesibukan mereka masing-masing dan ada yang tidak 
mendengarkan dengan baik materi yang disampaikan. Dalam proses diskusi kelompok juga hanya beberapa siswa saja yang terlibat aktif. Adapun tujuan dalam penelitian ini adalah untuk mengetahui adanya pengaruh model pemberdayaan berpikir melalui pertanyaan terhadap kemampuan berpikir kreatif siswa di SMP Negeri 10 kupang tahun ajaran 2019/2020.

\section{METODE PENELITIAN}

\section{Lokasi dan Waktu Penelitian}

Lokasi Penelitian

Penelitian ini dilaksanakan di SMP N 10 Kupang Jln. Prof. Dr. Herman Johanes Kelurahan Lasiana Kecamatan Kelapa Lima Kabupaten Kota Kupang Propinsi Nusa Tenggara Timur.

Waktu Penelitian

Penelitian ini dilaksanakan selama 1 bulan yakni dari tanggal 23 Juli-23 Agustus pada semester ganjil Tahun Ajaran 2019/2020.

\section{Metode Penelitian}

Metode penelitian yang digunakan dalam penelitian ini yaitu penelitian Quasi-Experimental Design atau eksperimen semu.

\section{Desain Penelitian}

Desain penelitian yang digunakan dalam penelitian berbentuk posttest-only control design. Untuk memperjelas bagaimana desain penelitian ini, berikut disajikan gambarannya dalam Tabel 1 berikut ini:

Tabel 1. Posttest-Only Control Design

\begin{tabular}{ccc}
\hline Kelompok & Perlakuan & Posttest \\
\hline $\mathrm{E}$ & $\mathrm{X}$ & 02 \\
\hline $\mathrm{K}$ & - & 04 \\
\hline
\end{tabular}

\section{Keterangan:}

$\mathrm{E}$ : Kelompok eksperimen

$\mathrm{K}$ : Kelompok kontrol

02 : Posttest Kelompok eksperimen

04 : Posttest Kelompok kontrol

$\mathrm{X}$ : Perlakuan dengan model PBMP

(Sugiyono, 2012)

\section{Populasi dan Sampel}

Populasi Penelitian

Populasi dalam penelitian ini adalah seluruh siswa kelas VIII SMP N 10 Kupang sebanyak 11 kelas mulai dari kelas VIII A-VIII K yang berjumlah 327 siswa.

Sampel Penelitian

Teknik yang digunakan dalam penelitian ini yaitu teknik purposive sampling. Sampel dalam penelitian ini menggunakan kelas VIII H yang berjumlah 32 siswa sebagai kelas eksperimen, dan kelas VIII J yang berjumlah 32 siswa sebagai kelas kontrol. Jumlah sampel dalam penelitian ini sebanyak 64 orang.

\section{Teknik Pengumpulan Data}

Teknik pengumpulan data yang digunakan dalam penelitian ini adalah tes berpikir kreatif. Tes adalah instrument pengumpulan data yang terdiri dari serangkaian pertanyaan atau latihan yang digunakan untuk mengukur keterampilan, pengetahuan, intelegensi, kemampuan atau bakat yang dimiliki oleh individu atau kelompok (Riduwan, 2004). Tes yang digunakan dalam penelitian 
ini adalah tes essay. Tes essay dalam penelitian ini digunakan untuk mengukur kemampuan berpikir kreatif siswa. Bentuk tes yang digunakan yaitu post-test only. Penilaian terhadap jawaban siswa kepada tes essay, dilakukan dengan menggunakan bantuan rubrik kemampuan berpikir kreatif biologi yang dikembangkan oleh Robitah (2014). Rublik penilaian ini mempunyai skor tertinggi yakni 4 dan skor terendah adalah 1.

\section{Teknik Analisis Data}

Dalam penelitian ini teknik analisis data yang digunakan yaitu menggunakan Uji-t dengan bantuan program komputer SPSS versi 19.

\section{HASIL DAN PEMBAHASAN}

\section{Deskripsi Data Kelas Eksperimen}

Data yang dikumpulkan dalam penelitian ini berupa data hasil kemampuan berpikir kreatif siswa yang diperoleh dari test yang diberikan kepada siswa. Dalam penelitian ini, peneliti memperoleh data dari hasil posttest. Adapun distribusi frekuensi hasil posttest kelas $\mathrm{VIII}^{\mathrm{H}}$ dapat dilihat pada Tabel 2.

Tabel 2. Distribusi Frekuensi Kelas VIII ${ }^{\mathrm{H}}$

\begin{tabular}{lrcc}
\hline No & Rentang Nilai & $F$ & Persentase \\
\hline 1 & $75-78$ & 6 & $18,75 \%$ \\
\hline 2 & $79-82$ & 5 & $15,625 \%$ \\
\hline 3 & $83-86$ & 5 & $15,625 \%$ \\
\hline 4 & $87-90$ & 14 & $43,75 \%$ \\
\hline 5 & $91-94$ & 1 & $3,125 \%$ \\
\hline 6 & $95-98$ & 1 & $3,125 \%$ \\
\hline & Jumlah Skor $(\Sigma)$ & 32 & $100 \%$ \\
\hline
\end{tabular}

Berdasarkan distribusi frekuensi hasil posttest, maka dapat digambarkan dalam bentuk grafik yang dapat dilihat pada Gambar 1.

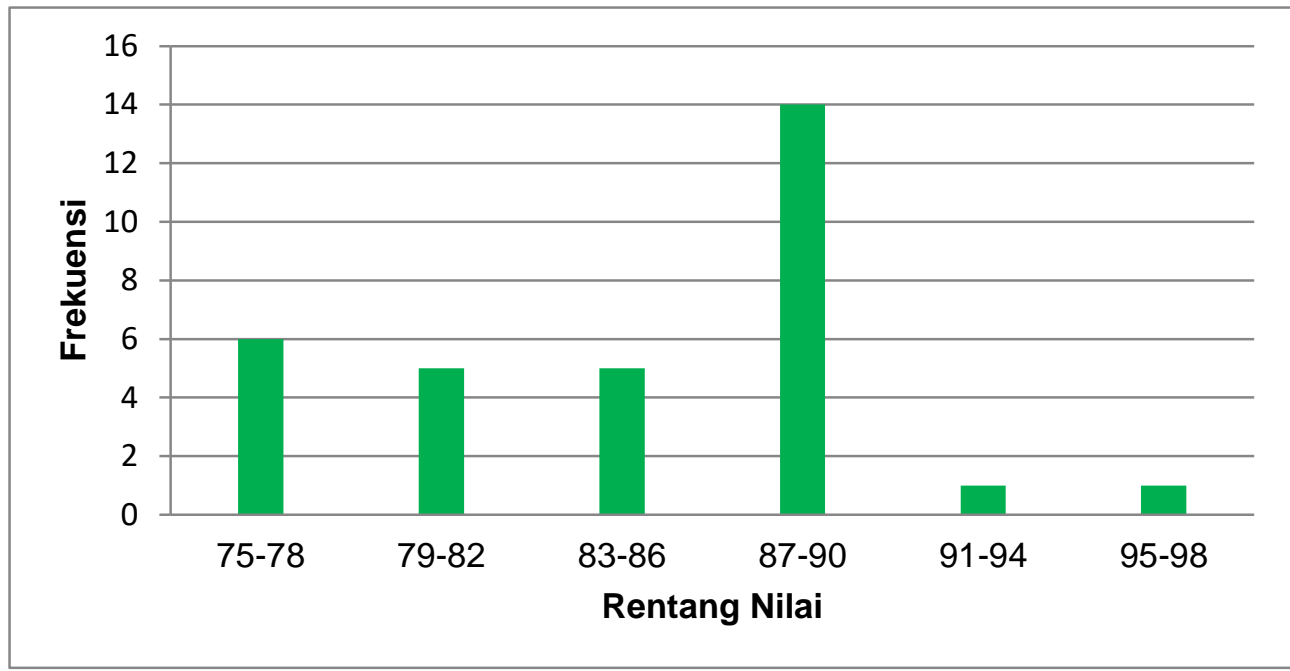

Gambar 1. Grafik Hasil Postest Kelas VIII 
Tabel dan diagram posttest siswa kelas $\mathrm{VIII}^{\mathrm{H}}$ menunjukan bahwa siswa memperoleh nilai dari 75-78 terdapat 6 siswa dengan persentase 18,75\%. Dari nilai 79-82 terdapat 5 siswa dengan persentase 15,625 \%. Dari nilai 83-86 terdapat 5 siswa dengan persentase 15,625 \%. Dari nilai 8790 terdapat 14 siswa dengan persentase 43,75\%. Dari nilai 91-94 terdapat 1 siswa dengan persentase 3,125 \%. Dari nilai 95-98 terdapat 1 siswa dengan persentase 3,125\%.

\section{Deskripsi Data Kelas Kontrol}

Data yang dikumpulkan dalam penelitian ini berupa data hasil kemampuan berpikir kreatif siswa yang diperoleh dari test yang diberikan kepada siswa. Dalam penelitian ini, peneliti memperoleh data dari hasil postest. Adapun distribusi frekuensi hasil posttest kelas $\mathrm{VIII}^{\mathrm{J}}$ dapat dilihat pada Tabel 3.

Tabel 3. Distribusi Frekuensi Kelas VIIIJ

\begin{tabular}{cccc}
\hline No & Rentang Nilai & $F$ & Persentase \\
\hline 1 & $62-64$ & 4 & $12,5 \%$ \\
\hline 2 & $65-67$ & 6 & $18,75 \%$ \\
\hline 3 & $68-70$ & 11 & $34,375 \%$ \\
\hline 4 & $71-73$ & 5 & $15,625 \%$ \\
\hline 5 & $74-76$ & 3 & $9,375 \%$ \\
\hline 6 & $77-79$ & 3 & $9,375 \%$ \\
\hline \multirow{2}{*}{ Jumlah Skor $(\Sigma)$} & 32 & $100 \%$ \\
\hline
\end{tabular}

Berdasarkan distribusi frekuensi hasil postest, maka dapat digambarkan dalam bentuk grafik yang dapat dilihat pada Gambar 2.

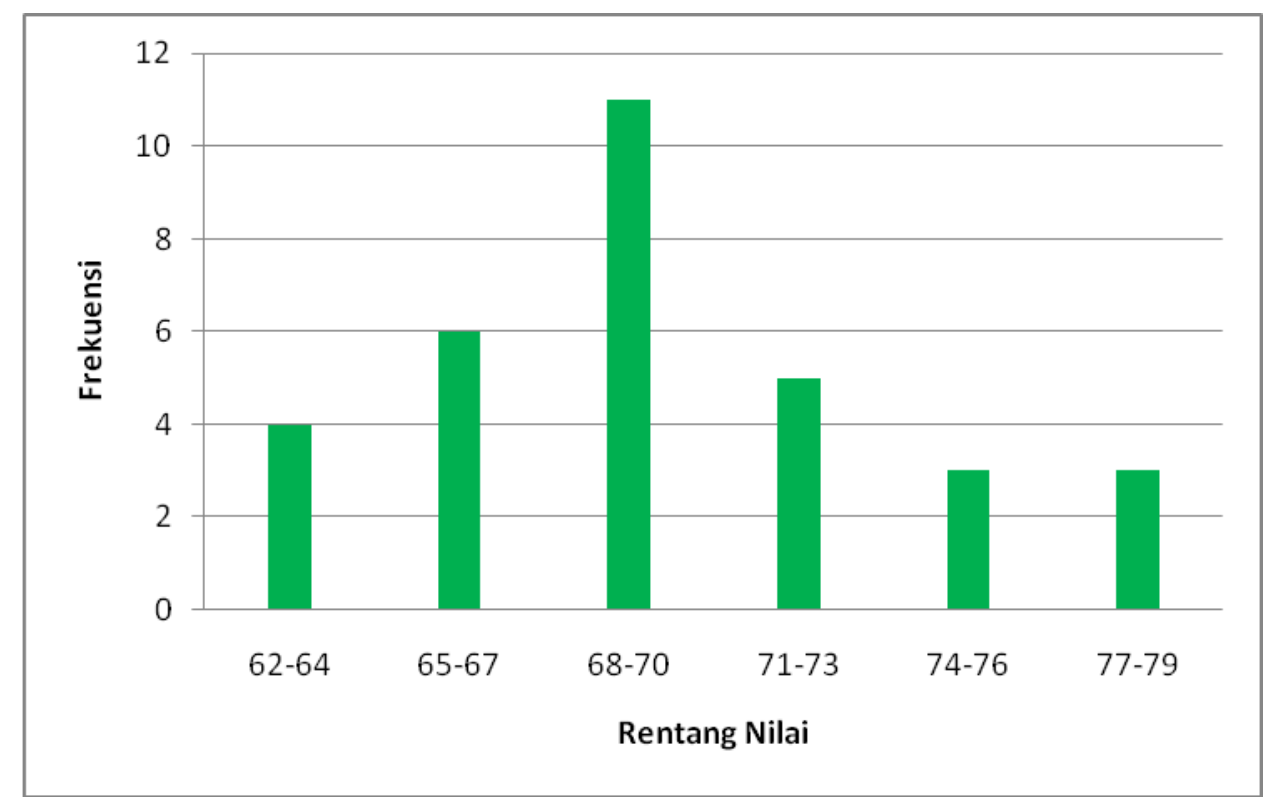

Gambar 2. Grafik Hasil Posttest Kelas VIIIJ 
Tabel dan diagram posttest siswa kelas $\mathrm{VIII}{ }^{\mathrm{J}}$ menunjukkan bahwa siswa memperoleh nilai dari 62-64 terdapat 4 siswa dengan persentase 12,5\%. Dari nilai 65-67 terdapat 6siswa dengan persentase 18,75 \%. Dari nilai 68-70 terdapat 11 siswa dengan persentase 34,375 \%.Dari nilai 7173 terdapat 5 siswa dengan persentase 15,625\%.Dari nilai 74-76 terdapat 3 siswa dengan persentase 9,375 \%. Dari nilai 77-79 terdapat 3 siswa dengan persentase 9,375\%.

\section{Deskripsi Kemampuan Berpikir Kreatif}

Rata-rata kemampuan berpikir kreatif siswa yang mengikuti pembelajaran menggunakan model PBMP dan pembelajaran yang menggunakan metode ceramah dapat dilihat pada Gambar 3.

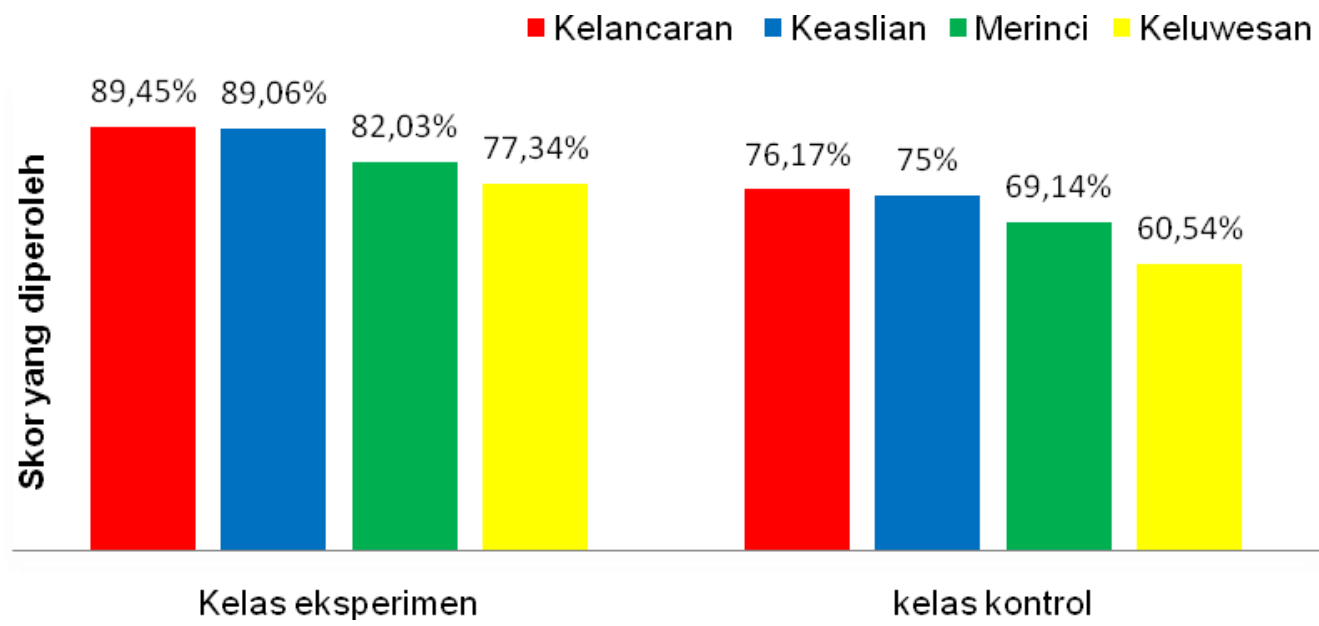

Gambar 3. Persentase Indikator Kemampuan Berpikir Kreatif Kelas VIIIH dan VIIIJ

Dari grafik persentase indikator berpikir kreatif siswa di atas dari hasil nilai posstest pada kelas eksperimen dan kelas kontrol dari hasil nilai posstest, secara umum terlihat bahwa pada berpikir lancar memiliki persentase tertinggi dari berpikir orisinil, merinci, dan luwes, baik pada kelas kontrol maupun kelas eksperimen. Secara khusus terlihat bahwa pada kelas eksperimen memilki persentase lebih tinggi dari kelas kontrol. Pada kelas eksperimen, berpikir lancar memilki persentase sebesar $89,45 \%$, berpikir orisinil memiliki persentase sebesar $89,06 \%$, merinci memiliki persentase sebesar $82,03 \%$ dan berpikir luwes memiliki persentase sebesar $77,34 \%$. Pada kelas kontrol berpikir lancar memilki persentase sebesar $76,17 \%$, berpikir orisinil memiliki persentase sebesar $75 \%$, merinci memiliki persentase sebesar $69,14 \%$ dan berpikir luwes memiliki persentase sebesar $60,54 \%$.

\section{Hasil Uji Hipotesis}

Hasil uji t untuk data kemampuan berpikir kreatif siswa dapat dilihat pada Tabel 4. Berdasarkan Tabel 4 di atas, diperoleh nilai Sig. (2-tailed) sebesar 0,000. Karena nilai Sig. (2tailed) $<0,05$ sehingga ada pengaruh model PBMP terhadap kemampuan berpikir kreatif siswa. 
Tabel 4. Independen Samples Test

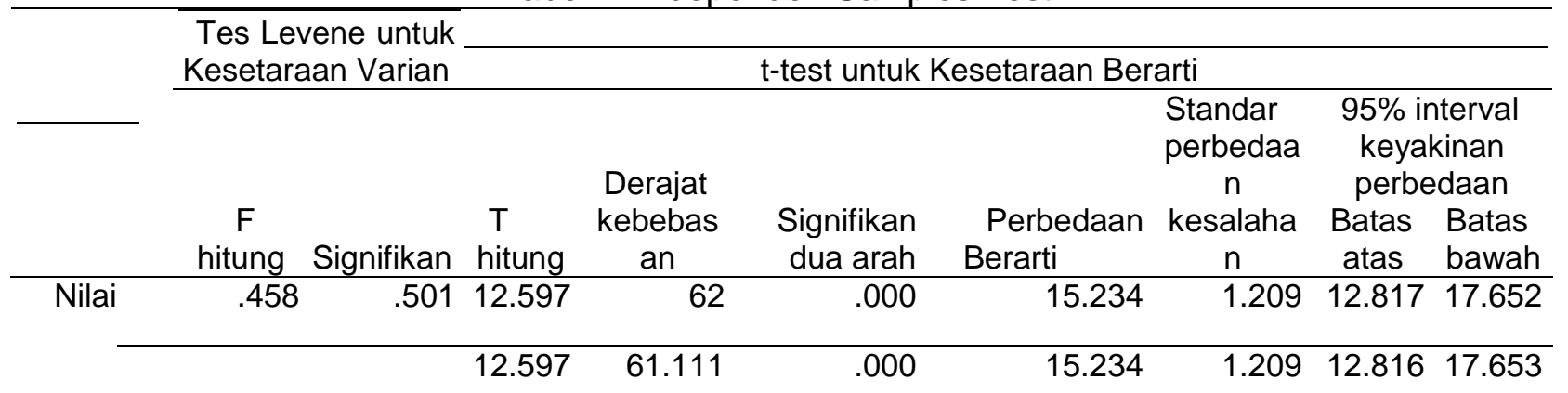

\section{Pembahasan}

Sumber: Outpus SPSS Versi 19

Berdasarkan hasil penelitian, dapat diketahui bahwa kemampuan berpikir kreatif pada kelas kontrol terlihat sangat rendah. Hal ini dikarenakan dalam penelitian pada kelas kontrol menggunakan metode ceramah, sehingga siswa hanya mendengarkan penjelasan dari guru. Dalam pelaksanaan pembelajaran keaktifan siswa kurang, karena siswa jenuh dan bosan mendengarkan penjelasan dari guru serta siswa kurang memperhatikan apa yang diajarkan guru, hal ini dikarenakan cara penyampaian materi pembelajaran belum dapat menimbulkan suasana yang menyenangkan. Dibandingkan dengan kelas eksperimen, siswa lebih aktif dalam proses pembelajaran yang diberikan perlakuan dengan model pembelajaran PBMP.

Selain itu juga pada kelas kontrol proses pembelajarannya membuat siswa kurang aktif di kelas, ini dikarenakan pembelajarannya berpusat pada guru sebagai pemberi informasi pengetahuan tentang materi sistem ekskresi pada manusia sehingga pembelajaran terkesan membosankan akibatnya kemampuan berpikir lancar, orisinil, merinci dan berpikir luwes di kelas kontrol rendah. Hal ini terlihat dari sikap siswa yang kurang siap untuk belajar dan sulit memahami konsep, hanya beberapa siswa yang serius dan aktif mengikuti proses pembelajaran sedangkan yang lainnya tidak memperhatikan tetapi sibuk dengan kegiatannya sendiri seperti bercerita dengan teman meskipun sudah ditegur oleh guru. Siswa jenuh dalam mengikuti proses pembelajaran, siswa hanya pasif mendengarkan materi yang disampaikan oleh guru. Sehingga siswa pada kelas kontrol nilai akhirnya pun masih terlihat rendah, terlihat pada saat guru memberikan test, siswa tidak menjawab soal dengan baik.Sehingga pembelajaran pada kelas kontrol tidak mampu meningkatkan kemampuan berpikir kreatif siswa.

Pembelajaran yang berlangsung pada kelas eksperimen, kemampuan berpikir kreatif siswa mengalami peningkatan karena dalam pelaksanaan proses pembelajaran diajarkan dengan model pembelajaran PBMP. Hal ini sependapat dengan hasil penelitian Corebima (2014) yang menyatakan ada perbedaan kemampuan berpikir kritis, motivasi dan pemahaman konsep biologi siswa secara signifikan antara pelajar yang diajarkan dengan model pembelajaran PBMP dengan model pembelajaran langsung. Dalam pelaksanaan pembelajaran dengan model PBMP terdapat satu variasi yang unik yakni siswa dituntut untuk bekerja sama dalam kelompok untuk menjawab pertanyaan yang disediakan dalam lembar LKS PBMP. Dengan adanya variasi ini menyebabkan siswa aktif dalam mencari informasi untuk menjawab setiap pertanyaan. Hal ini terlihat pada bagian "sediakan" dari model pembelajaran PBMP, siswa menyiapkan sendiri segala sesuatu yang diperlukan dalam mengerjakan pertanyaan-pertanyaan yang ada dalam lembar LKS. Pada bagian "lakukan" siswa sangat aktif mengerjakan LKS dalam kelompok mereka masingmasing.Sedangkan Pada bagian "renungkan" siswa terlihat sangat antusias menjawab pertanyaan yang ada dalam lembar LKS. Selain itu siswa juga berusaha mencari informasi dari berbagai media serta bertanya kepada guru jika kurang memahami tentang informasi yang di dapatkan sehingga siswa lebih aktif selama proses pembelajaran berlangsung.

Pada bagian "evaluasi", guru mengajukan pertanyaan dan siswa aktif menjawab pertanyaan, mengeluarkan ide dan pendapat tanpa merasa takut salah terhadap jawaban, ide dan pendapat yang disampaikan. Sehingga pemahaman terhadap materi pun dapat diserap dengan 
baik oleh siswa. Walaupun selama proses pembelajaran menggunakan model pembelajaran PBMP suasana kelas yang tampak terkesan ribut tetapi siswa dapat menyelesaikan tugas yang diberikan secara baik. Berkait dengan hal itu Atmah (2004) mengungkapkan bahwa pembelajaran dengan model PBMP dapat memotivasi siswa dalam menjelaskan ide, menjawab pertanyaan serta hasil belajar siswa tuntas. Menurut Corebima (2005) dengan model pembelajaran PBMP siswa akan terlatih untuk mengasah kemampuan berpikirnya melalui pertanyaan-pertanyaan yang ada. Pada saat siswa menjawab pertanyaan, siswa menuliskan kembali materi yang dipelajarinya.

Kelas eksperimen yang diajarkan dengan menggunakan model pembelajaran PBMP terlihat siswa begitu aktif karena dari langkah pembelajaran yang dilakukan pada kelas ini, siswa hanya diberi materi secara umum saja oleh guru pada awal pembelajaran setelah itu guru tidak lagi menjelaskan karena siswalah yang harus mencari sendiri informasinya dari berbagai media seperti buku dan handphone yang digunakan untuk membuka internet. Guru akan memberitahukan tentang tugas belajar yang harus dilakukan oleh siswa sambil memperhatikan jika ada kesulitan yang dihadapi sehingga dapat diberikan petunjuk bagi siswa. Hal ini akan memicu kemampuan berpikir kreatif siswa karena siswa mencari tahu sendiri informasi dan merasa bertanggungjawab dalam mengerjakan tugas dan menjawab pertanyaann-pertanyaan yang diberikan oleh guru. Sehingga pada proses pembelajaran guru hanya berperan sebagai fasilitator saja, karena selama proses pembelajaran di kelas eksperimen ini peran siswalah yang paling diutamakan sehingga siswa dapat mengembangkan berbagai potensi yang dimiliki oleh siswa.

Dari hasil penerapan Model PBMP, terlihat bahwa adanya peningkatkan yang terlihat pada kelas eksperimen, dimana pada berpikir lancar mendapatkan persentase sebesar $89,45 \%$, alasan bahwa pada aspek ini memiliki persentase yang lebih tinggi merupakan aspek berpikir yang paling mudah. Siswa dapat memberikan jawaban yang relevan, arus pemikiran siswa sangat lancar pada saat guru memberikan pertanyaan berkaitan dengan materi sistem eskresi. Pada berpikir orisinil mendapatkan persentase sebesar $89,06 \%$ karena pada aspek ini siswa dapat memberikan pendapat dan idenya sendiri terhadap pertanyaan yang diberikan oleh guru. Pada aspek merinci mendapatkan presentase sebesar $82,03 \%$ karena pada aspek ini siswa dapat menjelaskan serta mengembangkan suatu gagasan. Sedangkan pada berpikir luwes mendapatkan persentase sebesar 77,34\% karena siswa dapat menghasilkan gagasan-gagasan yan berbeda serta dapat memberikan jawabannya dari sudut pandang atau arah pemikiran yang berbeda. Hal ini sejalan dengan penelitian yang dilakukan Sukmawati (2013), PBMP terbukti dapat memperdayakan ketrampilan berpikir serta hal-hal lain terkait ketrampilan berpikir. Penelitian yang dilakukan Ekoningtyas (2013) membuktikan bahwa pembelajaran dengan PBMP dapat meningkatkan kemampuan berpikir kreatif.

Selain itu perbedaan ini juga dapat terlihat dari proses pembelajaran yaitu pada kelas eksperimen yang diajarkan dengan model pembelajaran PBMP memberi perubahan pada kemampuan berpikir kreatif siswa baik itu pada aspek berpikir lancar, orisinil, merinci maupun bepikir luwes, ditandai dengan keterlibatan siswa yakni mencari informasi sebanyak-banyaknya dari berbagai media untuk menjawab pertanyaan-pertanyaan yang diberikan kemudian mendiskusikan dengan teman sekelompoknya dan siswa juga tidak merasa bosan selama proses pembelajaran justru siswa terlihat lebih bersemangat. Pada kelas kontrol yang diajarkan dengan metode ceramah, kemampuan berpikir kreatif siswa kurang baik itu aspek berpikir lancar, berpikir orisinil, berpikir luwes maupun kemampuan merinci, hal ini terlihat dari siswa yang kurang aktif selama proses pembelajaran tetapi justru lebih aktif dalam melakukan kegiatan di luar materi yang dibahas selama proses pembelajaran.

Berdasarkan data empiris dan hasil perhitungan menggunakan uji statistik menunjukkan bahwa setelah digunakan model pembelajaran PBMP pada kelas eksperimen dan pembelajaran yang tidak menggunakan model pembelajaran PBMP pada kelas kontrol ini dapat terlihat bahwa kemampuan berpikir kreatif siswa kedua kelompok tersebut berbeda secara nyata. Hal tersebut bukan merupakan kebetulan tetapi hal ini merupakan akibat dari pemberian perlakuan yaitu penggunaan model PBMP pada kelas eksperimen. 
Hal ini dikarenakan kemampuan berpikir kreatif siswa mengalami perubahan terhadap kelas yang menggunakan model pembelajaran PBMP dengan kelas yang menggunakan metode ceramah. Dilihat dari skor nilai posstest siswa kelas eksperimen yang menggunakan model pembelajaran PBMP lebih tinggi dibandingkan skor nilai posstest siswa pada kelas kontrol yangmenggunakan metode ceramah. Perbedaan ini terjadi karena model pembelajaran PBMP memiliki kelebihan yaitu melatih kemampuan siswa belajar mandiri dalam mencari jawaban, sehingga kemampuan berpikir kreatif siswa meningkat. Dengan demikian terdapat perbedaan kemampuan berpikir kreatif siswa antara kelas eksperimen dan kelas kontrol sehingga ada pengaruh yang signifikan dari penggunaan model PBMP terhadap kemampuan berpikir kreatif siswa.

\section{KESIMPULAN}

Kesimpulan dari hasil penelitian ini adalah terdapat pengaruh model PBMP terhadap kemampuan berpikir kreatif siswa siswa di SMP Negeri 10 Kupang Tahun Ajaran 2019/2020 dilihat dari hasil uji- t yang memperoleh nilai Sig. (2-tailed) $<0,05$.

\section{DAFTAR PUSTAKA}

Atmah, 2004. Pengembangan Perangkat Pembelajaran Sains untuk SMP dan MTS Menerapkan pola Pemberdayaan Berpikir Melalui Pertanyaan pada Sistem Eskresi Pada Manusi. Surabaya.

Corebima, A. D. 2005. Pengukuran Kemampuan Berpikir. Makalah Pada Pelatihan PBMP bagi Guru dan Mahasiswa Sains Biologi dalam Rangka RUKK VA, 25 Juni 2005 di Malang.

Corebima, A. D. 2014. Pengaruh Pemberdayaan Berpikir Melalui Pertanyaan Terhadap Berpikir Kritis, Motivasi dan Pemahaman Konsep Biologi Siswa SMA Di Pasuruan. Malang: MIPA Universitas Negeri Malang.

Ekoningtyas, M.2013. Pengaruh Pembelajaran Think-Pair_Share dipadu Pola Pemberdayaan Berpikir melalui Pertanyaan Terhadap Ketrampilan Metakognitif, Berpikir Kreatif, Pemahaman Konsep IPA dan Retensinya serta Sikap Siswa. Jurnal Pendidikan Sains.

Istarani. 2011. 58 Model Pembelajaran Inovatif (Referensi Guru Dalam Menentukan Model Pembelajaran). Medan: Media Persada.

Mulyana. 2008. Model Tukar Belajar (Learning Exchange) dalam Perspektif Pendidikan. Bandung: Alfabeta.

Munandar. 2009. Pengembangan Kreatifitas Anak berbakat. Jakarta: Rineka Cipta

Riduwan. 2004. Metode dan Teknik Menyusun Tesis. Bandung: Alfabeta

Robitah, A. 2014. Pengaruh Pembelajaran Biologi berbasis Inkuiri dan Creative Problem Solving (CPS) terhadap Kemampuan Berpikir Kreatif, Keterampilan Proses IImiah dan Hasil Belajar Kognitif Siswa Kelas $X$. Tesis Tidak Diterbitkan. Malang: Universitas Negeri Malang

Rustaman. 2001. Keterampilan Bertanya dalam Pembelajaran IPA, Dalam Hand Out Bahan Pelatihan Guru-guru IPA SLTP Se-Kota Bandung di PPG IPA. Jakarta: Depdiknas

Sugiyono. 2011. Metode Penelitian Kuantitatif, Kualitatif dan R \& D. Bandung: Alfabeta.

Sugiyono. 2012. Metode Penelitian Kuantitatif Kualitatifdan R \& D. Bandung: Alfabeta

Sukmawati, I.2013. Perbandingan Keterampilan Metakognitif,Hasil Belajar Kognitif, Dan Retensi Pembelajaran Biologi Melalui Strategi PBMP PBMP Dipadu dengan TPS di Kalangan Siswa Berkemampuan Akademik Rendah. Skripsi Tidak Diterbitkan. Malang : FMIPA UM. 